\title{
TANTANGAN PENEGAKAN HAM KORPORASI
}

\author{
Oleh: Markus H Simarmata \\ Aparat Penegak Hukum \\ ilbesuccess@yahoo.com
}

\begin{abstract}
ABSTRAK
Komnas HAM menyatakan bahwa korporasi sering dilaporkan melanggar HAM. UndangUndang Nomor 32 Tahun 1999 tentang Pengelolaan dan Perlindungan Lingkungan Hidup juga mengamanatkan agar penegakan hukum pidana lingkungan dapat diterapkan terhadap korporasi yang melakukan pelanggaran terhadap kegiatan pengelolaan lingkungan hidup. Namun dalam peraturan perundang-undangan mengenai hak asaasi manusia dan penegakan hak asasi manusia belum diatur tentang pertanggungjawaban HAM Korporasi. Dalam penelitian ini metode yang digunakan adalah metode penelitian hukum normatif yang meneliti tentang pertanggungjawaban HAM korporasi yang melanggar hak atas lingkungan hidup berdasarkan Undang-Undang Nomor 39 Tahun 1999 tentang HAM dan peraturan perundang-undangan yang terkait lainnya. Peraturan perundang-undangan mengenai HAM yang belum mengatur tentang pertanggungjawaban HAM korporasi di antaranya yaitu Banyaknya peraturan perundang-undangan mengenai pertanggungjawaban HAM korporasi yang dibuat setelah Undang-Undang HAM pada tahun 1999 menyebabkan Undang-Undang Nomor 39 Tahun 1999 tidak sesuai lagi dengan ketentuan peraturan perundang-undangan yang baru. Di samping itu instrumen HAM internasional merupakan sarana "soft law" yang berisi himbauan sehingga tidak mengatur sanksi administratif, pidana, dan perdata bagi korporasi yang melanggar hak atas lingkungan hidup. Sedangkan penegakan HAM yang belum melaksanakan pertanggungjawaban HAM Korproasi yaitu tidak terdapatnya Putusan-Putusan Pengadilan yang mengungkapkan secara eksplisit pertanggungjawaban HAM korporasi. Untuk mengatasi hal tersebut seharusnya pemerintah segera merevisi Undang-Undang Nomor 39 Tahun 1999 dengan mengharmonisasikan ketentuan dalam UU HAM tersebut dengan peraturan perundang-undangan yang terkait dengan pertanggungjaaban HAM Korporasi. Selanjutnya mendorong negara-negara di dunia untuk merevisi instrumen HAM internasional yang mengatur sanksi administratif, pidana dan perdata bagi korporasi yang melanggar hak atas lingkungan hidup. Kemudian perlu melakukan bimbingan teknis bagi Hakim agar memiliki pengetahuan yang luas tentang pertanggungjawaban HAM korporasi sehingga dapat membuat Putusan Pengadilan yang mengungkapkan secara eksplisit pertanggungjawaban HAM korporasi.
\end{abstract}

Kata Kunci: Instrumen HAM Nasional; Instrumen HAM Internasional, Putusan Pengadilan.

\begin{abstract}
Komnas HAM stated that corporations often reported violating human rights. Law No. 32 of 1999 concerning Management and Protection of the Environment also mandates that the enforcement of environmental criminal law be applied to corporations that violate environmental management activities. However, legislation regarding human rights and enforcement of human rights has not been regulated regarding corporate human rights liability. In this study the method used is a normative legal research method that examines corporate human rights liability that violates the rights to the environment based on Law Number 39 of 1999 concerning Human Rights and other related laws and regulations. Laws
\end{abstract}


and regulations concerning human rights that have not regulated corporate human rights liability include the number of laws and regulations concerning corporate human rights liability made after the Human Rights Law in 1999 led to Law No. 39 of 1999 not in accordance with the provisions of the new legislation. In addition, international human rights instruments are a means of "soft law" which contains an appeal that does not regulate administrative, criminal and civil sanctions for corporations that violate the right to the environment. Then, there are no Court Decisions that explicitly disclose corporate human rights accountability. To solve this problem, the government should immediately revise Law No. 39 of 1999 by harmonizing the provisions in the Human Rights Law with the laws and regulations related to the Corporate Human Rights liability. Furthermore, encouraging countries in the world to revise international human rights instruments that regulate administrative, criminal and civil sanctions for corporations that violate environmental rights. Then, it is necessary to carry out technical guidance for judges to have extensive knowledge about corporate human rights accountability so that they can make Court Decisions that explicitly disclose corporate human rights accountability.

Keywords: National Human Rights Instruments; International Human Rights Instruments, Court Decisions.

\section{A. Pendahuluan}

Dalam Undang-Undang Dasar 1945 Pasal 28 ayat (1) mengatur agar setiap orang berhak hidup sejahtera lahir dan batin, bertempat tinggal, dan mendapatkan lingkungan hidup yang baik dan sehat serta berhak memperoleh pelayanan kesehatan. Amanat UUD 1945 tersebut dengan tegas mengatur bahwa kebutuhan mendapatkan lingkungan yang sehat merupakan salah satu hak asasi manusia. Untuk itu negara berkewajiban memenuhi dan melindungi masyarakat untuk memperoleh lingkungan yang sehat. Dasar konstitusional ini menghendaki pengaturan yang tegas terhadap pertanggungjawaban HAM termasuk korporasi Dalam pembakaran hutan dan lahan di Indonesia. ${ }^{1}$

Mahkamah Agung Republik Indonesia (MARI) pada kasus pembakaran lahan telah memvonis pertanggungjawaban pidana korporasi terhadap pembakaran lahan tersebut, yaitu PT KA dihukum dengan pidana denda sebesar $\mathrm{Rp}$ $366.000 .000 .000,00$ dengan uraian ganti

Indonesia, Undang-Undang Dasar 1945, Pasal 28 H ayat (1). ruginya sebagai berikut membayar ganti rugi material tunai kepada negara $\mathrm{Rp}$ 114.333.419.000,00 dan biaya pemulihan lingkungan atas lahan yang dibakar Rp 251.765.250.000,00 karena terbukti membakar 1.000 hektar lahan gambut ketika membuka perkebunan kelapa sawit di Suaq Bahong, Kecamatan Darul Makmur, Nagan Raya Aceh pada 20092012. ${ }^{2}$ Kemudian PT MPL dihukum dengan denda sebesar 16.244.574.805.000,00 $0^{3}$ karena melakukan penebangan hutan di luar lokasi Izin Usaha Pemanfaatn Hasil Hutan Kayu Hutan Tanaman (IUPHHK-HT) dan melakukan penebangan hutan di dalam lokasi IUPHHK-HT yang tidak sesuai jenis kayu yang seharusnya ditebang. ${ }^{4}$

Korporasi telah memberikan kontribusinya yang besar terhadap perekonomian Indonesia dengan menyediakan lapangan pekerjaan, meningkatkan penerimaan negara di sektor pajak dan menggalakkan program

MARI, Putusan Tertanggal 5 April 2010 Nomor 1554 K/Pid.Sus/2015.

Ibid.

MARI, Putusan Tertanggal 18 Agustus 2016, Nomor 460 K/Pdt/2016. 
CSR. Namun korporasi juga telah berperan terhadap peristiwa pelanggaran HAM di Indonesia.

Komite Nasional Hak Asasi Manusia (Komnas HAM) telah mereleas Laporan Tahunan Tahun 2015 yang menyatakan bahwa korporasi menempati urutan kedua setelah kepolisian sebagai pihak/institusi yang paling sering dilaporkan oleh masyarakat ke Komnas HAM terkait pelanggaran HAM. $^{5}$ Pada tahun yang sama Komnas HAM menerima 8.249 kasus pelanggaran HAM yang diadukan oleh masyarakat, tercatat bahwa institusi kepolisian menduduki urutan pertama yang paling sering diadukan, selanjutnya disusul oleh korporasi, pemerintah daerah, Tentara Nasional Indonesia (TNI), dan lembaga peradilan. ${ }^{6}$

Hal tersebut bertentangan dengan Pasal 28A UUD 1945 dan pasal 4 jo.Pasal 9 ayat (1) UU HAM Nomor 39 Tahun 1999 yang melanggar hak hidup, bertentangan dengan Pasal 28H ayat (1) UUD 1945 yang melanggar hak atas kesehatan, dan bertentangan dengan Pasal 9 ayat (3) UU HAM Nomor 39 Tahun 1999 yang melanggar hak atas lingkungan yang baik dan sehat. ${ }^{7}$

Berdasarkan penilaian Komnas HAM negara bertanggung jawab atas pembakaran lahan dan hutan pada tahun $2015^{8}$ namun Komnas HAM tidak menyebutkan korporasi sebagai pelaku pembakaran lahan dan hutan pada tahun 2015 di Indonesia.

Secara tegas Pasal 69 ayat (1) huruf $h$ UU PPLH Nomor 32 Tahun 2009 melarang setiap orang melakukan pembukaan lahan dengan cara membakar, selanjutnya Pasal 69 ayat (1) huruf a UU PPLH Nomor 32 Tahun 2009 juga melarang setiap orang

Komnas HAM, Laporan Tahunan Komnas HAM 2015, (Jakarta; Komnas HAM, 2016), hlm. 3.

6 Ibid.

Ibid

Ibid. melakukan pengrusakan dan atau pencemaran lingkungan hidup. Kemudian Pasal 108 UU PPLH Nomor 32 Tahun 2009 mengatur bahwa sanksi pidana paling singkat 3 tahun dan paling lama 10 tahun, dan denda paling sedikit 3 miliar Rupiah dan paling banyak 10 miliar Rupiah terhadap setiap orang yang melanggar Pasal 69 ayat (1) huruf h UU PPLH Nomor 32 Tahun 1999.

Penjelasan UU Nomor 32 Tahun 1999 mengamanatkan agar penegakan hukum pidana lingkungan dapat diterapkan sebagai pilihan utama terhadap setiap korporasi yang melakukan kegiatan usaha dalam pengelolaan lingkungan hidup selain pemidanaan terhadap pelanggaran baku mutu air limbah, emisi dan gangguan. ${ }^{9}$

Coleman menyatakan bahwa dalam strict liability, penggugat memiliki beban untuk membuktikan bahwa: a) tergugat telah melakukan sebuah kegiatan, b). Penggugat telah mengalami kerugian; dan c) bahwa bahwa kerugian tersebut disebabkan oleh kegiatan tergugat. ${ }^{10}$

Berdasarkan pendapat tersebut tidak tepat dikatakan bahwa strict liability adalah pertanggungjawaban tanpa pembuktian mengenai kausalitas perbuatan tergugat yang telah menyebabkan kerugian penggugat dan tidak tepat juga dikatakan bahwa strict liability adalah pembuktian terbalik. Strict

9 Maret Priyanta, Penerapan Tindak Pidana Lingkungan Bagi Korporasi dalam Penegakan Hukum Lingkungan di Indonesia, Jurnal Law Review Fakultas Hukum Universitas Pelita Harapan (UPH) Vol. XI Nomor 3 Maret 2012.

10 Coleman juga menyatakan bahwa berbeda denga pembuktian pada strict liability, pembuktian dalam negligence mensyaratkan penggugat untuk membuktikan bahwa: a) Tergugat telah melakukan kegiatan; b) Tergugat telah melakukan kesalahan (melawan hukum) dalam menjalankan perbuatannya, c) penggugat mengalami kerugian; dan d) Kerugian tergugat disebabkan oleh perbuatan tergugat yang salah tersebut, Jules L Coleman, Risks and Wrongs (Cambridge University Press, 1992), hlm.212. 
liability juga mewajibkan penggugat untuk membuktikan beberapa hal. Dalam strict liability, tergugat dapat menghindari pertanggungjawaban jika tergugat tersebut dapat membuktikan beberapa hal. Alasan untuk menghindari inilah yang membedakan antara strict liability dengan absolute liability. Strict liability tidak penuh absolut, karena dalam strict liability masih harus memberikan beberapa alasan pembelaan atau defense yang dapat dijadikan sarana untuk menghindari pertanggungjawaban.

Pendapat ini dikemukakan oleh Palmer, yang mengatakan bahwa pembeda utama absolute liability dari strict liability adalah bahwa dalam absolute liability terdapat "total (or virtually total) rejection of defenses of any kind, wheter we speak of defenses that negate causation, defenses that inculpate the plaintiff, or defenses that exonerate the defendant."11

Dalam hukum pidana di Australia yaitu Criminal Code Act of 1995 juga menggunakan strict liability dalam Kitab Undang-Undang Hukum Pidananya. ${ }^{12}$ Agar strict liability dalam perkara pidana tidak disalahgunakan maka menurut Parliament of New South Wales terdapat beberapa kriteria yang harus dipenuhi, yaitu:

a. Penerapan strict liability dalam kasus pidana harus mempunyai alasanalasan/justifikasi untuk kepentingankepentingan umum (the public interests);

b. Penerapan strict liability ditujukan untuk kepentingan perlindungan

11 Vernnn Palmer, "A General Theory of The Inner Structure of Strict Liability: Common Law, Civil Law, and Comparative Law", Tulane Law Review, Vol.62, 1988, hlm. 1329.

12 Parliament of New South Wales, Legislation Review Committee: Strict and Absolute Liability Discussion Paper, (NSW: Parliament of New South Wales, 2006), hlm. 3-4. lingkungan hidup atau keselamatan publik;

c. Strict liability harus fokus terhadap tindakan atau tindakan yang seharusnya dilakukan oleh pihak yang bertanggung jawab untuk itu. ${ }^{13}$

Berdasarkan pendapat Coleman dan Parliament of New South Wales Australia tersebut, maka strict liability dapat digunakan dalam kasus pidana untuk kepentingan perlindungan lingkungan hidup. Kemudian abnormally dangerous activity itu sesungguhnya merupakan in tort law, an activity that (1) is not a common usage, and (2) creates a forseeable and highly significant risk of physical harm even when reasonable caris exercised by all actors. A person who is found by a court to have carried on an abnormally dangerous activity will be subject tostrict liability for physical harm resulting from that activity. ${ }^{14}$ Setelah melakukan analisis terhadap definsi tersebut penulis berkesimpulan makna dari abnormally dangerous activity itu adalah usaha/kegiatan yang tidak umum, dapat diperkirakan aktivitas/usaha tersebut sangat berisiko terhadap fisik manusia dan/atau kerusakan serius terhadap lingkungan hidup.

Asas strict liability jarang digunakan oleh pengadilan dalam kasus pidana atau perdata lingkungan. Terdapat beberapa kasus gugatan perdata lingkungan pembakaran hutan dan lahan yang telah diputus oleh pengadilan negeri yang menerapkan asas strict liability. PN Jakarta Selatan mengabulkan gugatan KKLH dan menyatakan PT WAJ bertanggung jawab atas pembakaran lahan seluas 1.626,23 hektar di Kabupaten Ogan Komering ilir Provinsi Sumatera Selatan pada 2015, dan

13 Ibid.

14 Abnormally Dangerous Activity, Legal Information Institute, (7 Mei 2017), https://www.law.cornell.edu/wex/abnormally _dangerous_activity. 
menyatakan pula PT NSP bertanggung jawab atas pembakaran lahan. ${ }^{15}$

PN Jakarta Selatan menerapkan asas strict liability dalam memvonis dua kasus kebakaran hutan tersebut, dan walaupun putusan-putusan tersebut belum memiliki kekuatan hukum tetap. Namun terlihat ada keinginan dari hakim untuk menggunakan asas strict liability di dalam kasus-kasus lingkungan hidup terutama pembakaran hutan dan lahan. Dengan jelas dan tegas Putusan Pengadilan tersebut menunjukkan bahwa pembakaran lahan dan hutan merupakan kejahatan lingkungan.

Tidak disebutkan dan dijelaskan dengan tegas dalam Undang-Undang HAM Nomor 39 Tahun 1999 bahwa korporasi sebagai pelaku pelanggaran HAM.

Pelanggaran HAM menurut Pasal 1 angka ke 6 UU HAM Nomor 39 Tahun 1999 adalah setiap perbuatan seseorang atau sekelompok orang termasuk aparat negara baik disengaja atau kelalaian yang secara melawan hukum mengurangi, menghalangi, membatasi, dan atau mencabut HAM seseorang atau sekelompok orang yang dijamin di dalam undang-undang ini, dan tidak mendapatkan atau dikhawatirkan tidak akan menyelesaikan permasalahan hukum secara adil dan benar, berdasarkan mekanisme hukum yang berlaku. Selanjutnya undang-undang tersebut tidak menyebutkan atau menjelaskan tanggung jawab korporasi dalam HAM namun Pasal 71 UU HAM Nomor 39 Tahun 1999 hanya menjelaskan kewajiban dan tanggung jawab negara dalam menghormati, melindungi, menegakkan dan memajukan HAM.

Komisi Nasional Hak Asasi Manusia (Komnas HAM) mengakui kesulitan untuk

15 Srict Liability di dalam Kasus Pembakaran Hutan, (10 Februari 2017), Harian Kompas. mengkategorikan korporasi sebagai subjek hukum yang bertanggung jawab atas pelanggaran HAM karena sulit membuktikan unsur kesalahan yang disengaja atau mental state dari korporasi tersebut. $^{16}$ Selanjutnya terdapat perbedaan pendapat di kalangan sarjana hukum tentang dapatkah korporasi diminta pertanggungjawaban HAM apabila melanggar HAM. Dengan demikian belum terdapat kejelasan secara hukum apakah korporasi yang melakukan pembakaran hutan dapat diminta pertanggungjawaban HAMnya. keadaan tersebut menunjukkan terdapat kekosongan hukum dan berbagai penafsiran tentang dapatkah korporasi diminta pertanggungjawaban HAM terutama dalam kasus pembakaran hutan dan lahan di Indonesia.

Berdasarkan uraian tersebut maka penulis tertarik untuk menganalisis artikel ini dengan judul "Pertanggungjawaban HAM Korporasi Yang Melanggar Hak Atas Lingkungan hidup".

Untuk memahami lebih dalam tentang pertanggungjawaban HAM korporasi tersebut maka penulis merumuskan permasalahan mengenai Bagaimanakah pertanggungjawaban korporasi terhadap perusakan lingkungan menurut instumen HAM Nasional? Bagaimanakah pertanggungjawaban korporasi terhadap perusakan lingkungan menurut instumen HAM internasional? dan Bagaimanakah pertanggunjawaban korporasi terhadap perusakan lingkungan menurut Putusan-Putusan Pengadilan?

\section{B. Metode Penelitian}

Berdasarkan pendapat Morris L.Cohen penelitian hukum merupakan proses penemuan hukum yang mengatur

16 Adoniati Meyria, Pertanggungjawaban Pidana Korporasi Dalam Pelanggaran HAM Berat, Majalah Wacana HAM Komnas HAM (Edisi 1 tahun XI 2013), hlm. 9. 
kegiatan dalam masyarakat manusia. ${ }^{17}$ Sedangkan menurut Nexis Lexis, penelitian hukum merupakan proses pengidentifikasian dan memperoleh informasi yang dibutuhkan untuk mendukung pengambilan keputusan hukum. ${ }^{18}$ Dari kedua pendapat tersebut maka dapat disimpulkan penelitian hukum merupakan proses penemuan hukum yang mengidentifikasi dan memberikan informasi yang penting untuk mendukung pengambilan keputusan hukum yang mengatur kegiatan dalam masyarakat manusia.

Sedangkan tujuan dari penelitian hukum adalah untuk mencari kebenaran normatif. ${ }^{19}$ Selanjutnya terdapat pula pendekatan-pendekatan di dalam penelitian hukum yaitu pendekatan perundang-undangan, pendekatan kasus, pendekatan historis, pendekatan komparatif, dan pendekatan konseptual. ${ }^{20}$

Dalam penelitian ini penulis akan menggunakan metode penelitian hukum normatif yang meneliti tentang pertanggungjawaban HAM korporasi yang melanggar hak atas lingkungan hidup yang bersumber dari Undang-Undang Nomor 39 Tahun 1999 tentang HAM dan peraturan perundang-undangan yang terkait lainnya sebagai sumber hukum primer dan buku-buku, jurnal, majalah, koran, dan internet yang memuat pendapat para ahli HAM, hukum pidana, perdata dan lingkungan hidup sebagai sumber hukum sekunder.

Analisis yang dilakukan penulis yaitu menggunakan pendekatan perundangundangan terhadap UU Nomor 39 Tahun 1999 tentang HAM, UU Nomor 32 tahun

17 Morrish L. Cohen \& Kent C Olson, Legal Research In A Nutshell, (st.Paul $\mathrm{M}<$ inn: West Publishing Co, 1992), hlm. 1.

18 Lexis-Nexis, An Introduction to legal Research, hlm. 3.

19 Peter Mahmud Marzuki, Penelitian Hukum Edisi Revisi, (Jakarta: Prenada Media Group, 2014), hlm. 47.

20 Ibid, hlm. 133.
2009 tentang Perlindungan dan Pengelolaan Lingkungan Hidup, PutusanPutusan MARI tentang tanggung jawab korporasi dalam kasus pembakaran hutan, selain itu juga menggunakan pendekatan kajian putusan-putusan pengadilan baik dalam kasus pertanggungjawaban pidana maupun perdata pembakaran maupun penebangan hutan, dan juga menggunakan pendekatan komparatif yang membandingkan ketentuan hukum pidana, perdata, dan HAM tentang pertanggungjawaban korporasi terhadap pelanggar lingkungan hidup untuk menjawab isu hukum tersebut.

Pendekatan perundang-undangan berdasarkan pendapat Johny Ibrahim yaitu pendekatan yang memiliki sifat:

a. Comprehensive, yaitu melihat norma dalam peraturan perundang-undangan berkait satu dengan yang lain;

b. All-inclusive yaitu memandang sekumpulan norma hukum tersebut mampu menampung permasalahan hukum yang ada, sehingga tidak ada kekurangan hukum;

c. Systematic, yaitu selain norma hukum itu berhubungan satu dengan yang lainnya, norma hukum tersebut tersusun secara sistematis. ${ }^{21}$

Berikutnya, pendekatan kasus merupakan penelaahan putusan-putusan pengadilan yang sudah mempunyai kekuatan hukum tetap, dengan tujuan untuk mengetahui pertimbanganpertimbangan hukum dalam memutus kasus-kasus tersebut. ${ }^{22}$ Kemudian, pendekatan komparasi dilakukan dengan cara membandingkan UU atau putusan pengadilan dalam kasus yang sama dari satu atau lebih negara, dengan tujuan untuk mendapatkan pemahaman konsistensi antara filosofi dan UU atau

21 Johny Ibrahim, Teori dan Metodologi Penelitian Hukum Normatif (Malang : Bayumedia, 2005), hlm. 303.

22 Marzuki, Op.Cit, hlm. 134. 
putusan pengadilan di antara negaranegara tersebut. ${ }^{23}$

\section{Pembahasan}

\section{Pertanggungjawaban Korporasi} Terhadap Perusakan Lingkungan Menurut Instrumen HAM Nasional

Dalam konstitusi Indonesia pada Pasal 281 ayat (4) disebutkan tanggung jawab negara, khususnya pemerintah terhadap HAM dengan menyatakan bahwa perlidungan, pemajuan, penegakan, dan pemenuhan HAM adalah tanggung jawab negara terutama pemerintah. Ketentuan ini dipertegas dalam Pasal 71 UU Nomor 39 Tahun 1999 tentang HAM yang menyatakan bahwa pemerintah wajib dan bertanggung jawab menghormati, melindungi, menegakkan dan memajukan hak asasi manusia yang diterima oleh negara Republik Indonesia.

Menurut Komnas HAM makna menghormati HAM sebagaimana yang diamanatkan dalam Pasal 71 UU HAM tersebut yaitu bahwa negara tidak boleh ikut campur yang dapat mengganggu penikmatan HAM; sedangkan makna melindungi HAM yang juga diamanatkan dalam Pasal 71 UU HAM tersebut yaitu bahwa negara harus melindungi HAM setiap orang atas pelanggaran HAM yang dilakukan oleh pihak ketiga, dengan melalui pembentukan dan penegakan peraturan perundang-undangan. ${ }^{24}$

Menurut Pasal 1 angka 1 UU Nomor 39 Tahun 1999 Hak Asasi Manusia adalah seperangkat hak yang melekat pada hakikat dan keberadaan manusia sebagai mahluk Tuhan Yang Maha Esa dan merupakan anugerah-Nya yang wajib dihormati, dijunjung tinggi oleh negara, hukum, pemerintah, dan setiap orang demi kehormatan serta perlindungan harkat dan martabat manusia.

23 Ibid, hlm. 135.

24 Komnas HAM, Komentar Umum atas Kovenan Hak-Hak Sipol dan Ekosob (Jakarta: Komnas HAM, 2009), hlm. 3. $\begin{array}{ccr}\text { Besarnya } & \text { kepedulian } & \text { Negara } \\ \text { terutama } & \text { pemerintah } & \text { terhadap } \\ \text { kesejahteraan } & \text { masyarakat } & \text { melalui }\end{array}$ pengelolaan lingkungan hidup yang melindungi dan melestarikan lingkungan hidup yang baik dan sehat telah diamanatkan dalam Konstitusi Indonesia yang tercantum dalam Pasal $28 \mathrm{H}$ ayat (1), dan Pasal 33 ayat (4) UUD 1945. Oleh karena itu UUD 1945 merupakan konstitusi hijau (green constitution) karena berdasarkan Pasal $28 \mathrm{H}$ ayat (1), Pasal 33 ayat (4) UUD 1945 yang secara eksplisit mengakui hak atas lingkungan hidup dan kesehatan. ${ }^{25}$

Banyaknya peraturan perundangundangan yang dibuat setelah UndangUndang HAM pada tahun 1999 menyebabkan Undang-Undang Nomor 39 Tahun 1999 tidak sesuai lagi dengan ketentuan peraturan perundangundangan yang baru. Hal ini sesuai dengan asas hukum perundang-undangan yang menyatakan peraturan perundangundangan yang baru mengesampingkan perundang-undangan lama atau Lex Posterior Derogat Legi Priori. ${ }^{26}$ Banyaknya peraturan perundangundangan yang diubah atau direvisi tersebut bertujuan untuk mengatur halhal atau kegiatan-kegiatan tentang pengelolaan dan perlindungan lingkungan hidup yang mengalami perkembangan dari ketentuan peraturan perundangundangan sebelum-nya atau untuk mengatur hal-hal atau kegiatan-kegiatan tentang pengelolaan dan perlindungan lingkungan hidup yang belum pernah diatur dari ketentuan peraturan perundang-undangan sebelum-nya dalam

25 Jimly Assiddiqie, Green Constitution: Nuansa Hijau UUD Republik Indonesia Tahun 1945, (Jakarta: Rajawali Press, 2009), hlm. 179.

26 Ferry Irawan Febriansyah, Konsep Pembentukan Peraturan Perundang-undangan di Indonesia, Perspektif, Volume XXI No. 3 Tahun $2016 \quad$ Edisi September, <http://oaji.net/articles/2017/46741495161502.pdf> hlm. 223. 
rangka melaksanakan amanat Konstitusi Republik Indonesia yaitu memenuhi hak setiap orang untuk memperoleh lingkungan hidup yang baik dan sehat. Terdapatnya kesenjangan peraturan lingkungan hidup dengan UU HAM tersebut mengakibatkan perlunya merevisi pasal-pasal yang terkait dengan hak atas lingkungan hidup yang sehat sesuai dengan ketentuan Undang-Undang yang lebih baru tersebut. Kemudian norma lingkungan hidup telah mengalami konstitusionalisasi menjadi materi muatan konstitusi sebagai hukum tertinggi, sehingga segala kebijakan dan tindakan pemerintah dan pembangunan haruslah tunduk kepada ketentuan mengenai HAM atas lingkungan hidup yang baik dan sehat, dan tidak boleh ada kebijakan yang tertuang dalam bentuk UU atau peraturan di bawah UU yang bertentangan dengan ketentuan konstitusi yang pro lingkungan. ${ }^{27}$

Penjelasan UU Nomor 32 Tahun 1999 telah mengamanatkan agar penegakan hukum pidana lingkungan dapat diterapkan sebagai pilihan utama terhadap setiap korporasi yang melakukan kegiatan usaha dalam pengelolaan lingkungan hidup selain pemidanaan terhadap pelanggaran baku mutu air limbah, emisi dan gangguan. Dari ketentuan tersebut sangat tegas diatur tentang pertanggungjawaban pidana korporasi melanggar UU Pengelolaan Lingkungan Hidup. Namun ketentuan ini tidak terdapat dalam peraturan perundang-undangan yang terkait seperti UU HAM, UU Perseroan Terbatas (PT), UU Perbankan, dan UU Penanaman Modal (PM). ${ }^{28}$ Walaupun Undang-Undang tersebut telah mengatur aktivitas atau

27 Ibid, hlm. 180

28 Muhamad Insa Ansari, Implikasi Pengaturan Lingkungan Hidup terhadap Peraturan Perundang-undangan Dalam Kegiatan Bisnis (Perspektif Konstitusi), Jurnal Konstitusi (MK) Volume 11 Nomor 2, 2014. kegiatan bisnis korporasi yang memperhatikan kelestarian lingkungan hidup, tetapi jika dianalisis lebih mendalam ternyata belum terdapat ketentuan mengenai pertanggungjawaban HAM Korporasi yang merusak atau mencemari lingkungan hidup.

Pada Pasal 1 angka 6 UU Nomor 39 tahun 1999 disebutkan bahwa pelanggaran HAM adalah setiap perbuatan seseorang atau kelompok orang termasuk aparat negara baik disengaja maupun tidak disengaja atau kelalaian yang secara melawan hukum mengurangi, meng-halangi, membatasi, dan/atau mencabut hak asasi manusia seseorang atau kelompok orang yang dijamin oleh undang-undang ini, dan tidak mendapatkan, atau dikhawatirkan tidak memperoleh penyelesaian hukum yang adil dan benar, berdasarkan mekanisme hukum yang berlaku. Dari pengertian ini sangat jelas bahwa UU HAM tidak mengatur perbuatan atau aktivitas korporasi baik disengaja maupun tidak disengaja atau kelalaian yang secara melawan hukum mengurangi, menghalangi, membatasi, dan/atau mencabut hak asasi manusia seseorang atau kelompok orang yang dijamin oleh undang-undang, dan tidak mendapatkan, atau dikhawatirkan tidak memperoleh penyelesaian hukum yang adil dan benar, berdasarkan mekanisme hukum yang berlaku.

Secara etimologis, pengertian korporasi yang dalam istilah lain dikenal dengan corporatie (Belanda), corporation (Inggris), Korporation (Jerman), berasal dari bahasa Latin yaitu "corporation". Dengan demikian, maka akhirnya "corporation" itu berarti hasil pekerjaan membadankan, dengan perkataan lain, korporasi merupakan badan yang dijadikan orang, badan yang diperoleh dengan perbuatan manusia sebagai lawan terhadap badan manusia, yang terjadi 
menurut alam. Dalam arti luas korporasi meliputi baik badan hukum maupun bukan badan hukum, bukan saja badanbadan hukum seperti perseroan terbatas, yayasan, koperasi atau perkumpulan yang telah disahkan sebagai badan hukum yang digolongkan sebagai korporasi, tetapi juga firma, persekutuan komanditer atau CV, dan persekutuan atau maatschap, yaitu badan-badan usaha yang menurut hukum perdata bukan suatu badan hukum. ${ }^{29}$ Secara terminologi korporasi mempunyai pengertian yang sudah banyak dirumuskan oleh beberapa tokoh hukum. Semisal menurut Subekti dan Tjitrosudibo yang dimaksud dengan corporatie atau korporasi adalah suatu perseorangan yang merupakan badan hukum. Sedangkan Yan Pramadya Puspa menyatakan yang dimaksud dengan korporasi adalah suatu perseorangan yang merupakan badan hukum; korporasi atau perseroan di sini yang dimaksud adalah suatu perkumpulan atau organisasi yang oleh hukum diperlukan seperti seorang manusia (persona) ialah sebagai pegemban (atau pemilik) hak dan kewajiban memiliki hak menggugat ataupun digugat di muka pengadilan. ${ }^{30}$ Selanjutnya definisi korporasi menurut Pasal 1 Peraturan Mahkamah Agung RI Nomor 13 Tahun 2016 tentang Tata Cara Penanganan Perkara Tindak Pidana oleh Korporasi yaitu kumpulan orang dan/atau kekayaan yang terorganisir, baik merupakan badan hukum maupun bukan badan hukum.

Berdasarkan pendapat ahli maupun Perma Nomor 13 Tahun 2016 maka dapat

29 Muladi dan Dwidja Prayitno dalam Kristian, Urgensi Pertanggungjawaban Pidana Korporasi, Jurnal Hukum dan Pembangunan Tahun Ke-44 No.4 Oktober-Desember, 2013 , hlm. 579.

30 A.Ritonga, Korporasi Yang Melakukan Tindak Pidana Korporasi Pada Pasal 20 UU No. 31 Tahun 1999 jo. UU No. 20 Tahun 2001 tentang Pemberantasan Tindak Pidana Korupsi Menurut Perspektif Fiqih Jinayah, UIN Sultan Syarif Kasim Riau, Pekanbaru, 2015, hlm. 15. disimpulkan bahwa korporasi adalah kumpulan orang dan/atau kekayaan yang terorganisir, baik merupakan badan hukum yang meliputi perseroan terbatas, yayasan, koperasi atau perkumpulan yang telah disahkan sebagai badan hukum maupun bukan badan hukum yang meliputi firma, persekutuan komanditer atau CV, dan persekutuan atau maatschap. Definisi korporasi tersebut sebaiknya dicantumkan dalam UU Nomor 39 Tahun 1999 tentang HAM sehingga definisi pelanggaran HAM juga mencakup pelanggaran yang dilakukan oleh korporasi.

Di samping itu terdapat ketentuan yang baru mengenai penegakan hukum yang diatur dalam UU Nomor 23 Tahun 2009 tentang Perlindungan dan Pengelolaan Lingkungan Hidup. Ketentuan penegakan hukum yang baru tersebut layak untuk diselaraskan dengan UU Nomor 39 Tahun 1999, yang mencakup antara lain: penyelesaian sengketa lingkungan hidup di luar pengadilan, gugatan perwakilan kelompok, hak gugat organisasi lingkungan sebagai bentuk partisipasi masyarakat terhadap hak atas lingkungan hidup. Melalui cara tersebut diharapkan selain akan menimbulkan efek jera juga akan meningkatkan kesadaran seluruh pemangku kepentingan tentang betapa pentingnya perlindungan dan pengelolaan lingkungan hidup demi kehidupan generasi masa kini dan masa depan.

Ketentuan penegakan hukum pidana yang baru yang terdapat dalam UU Perlindungan dan pengelolaan Lingkungan Hidup tersebut juga perlu dimuat dalam UU Hak Asasi Manusia. Ketentuan tersebut mencakup ancaman hukuman minimum di samping maksimum, perluasan alat bukti, keterpaduan penegakan hukum pidana, dan pengaturan tindak pidana korporasi. Di samping itu penerapan asas ultimum remedium juga hanya berlaku bagi tindak 
pidana formil tertentu, yaitu pemidanaan terhadap pelanggaran baku mutu air limbah, emisi, dan gangguan.

Ketentuan tentang pertanggungjawaban korporasi dalam UU No.32 Tahun 2009 terdapat dalam Pasal 116. Menurut penulis ketentuan ini dapat dipertimbangkan untuk diselaraskan dalam ketentuan HAM yang dapat dalam UU Nomor 39 Tahun 1999. Pasal 116 UU No.32 Tahun 2009 mengamanatkan:

(1) Apabila tindak pidana lingkungan hidup dilakukan oleh, untuk, atau atas nama badan usaha, tuntutan pidana dan sanksi pidana dijatuhkan kepada:

a. Badan usaha; dan/atau

b. Orang yang memberi perintah untuk melakukan tindak pidana tersebut atau orang yang bertindak sebagai pemimpin kegiatan dalam tindak pidana tersebut.

(2) Apabila tindak pidana lingkungan hidup sebagaimana dimaksud pada ayat (1) dilakukan oleh orang yang berdasarkan hubungan kerja atau berdasarkan hubungan lain yang bertindak dalam lingkup kerja badan usaha, sanksi pidana dijatuhkan terhadap pemberi perintah atau pemimpin dalam tindak pidana tersebut tanpa memperhatikan tindak pidana tersebut dilakukan secara sendiri atau bersama-sama.

Selain itu, Jaksa Agung juga mengeluarkan Peraturan Jaksa Agung RI Nomor Per-028/A/JA/10/2014 tentang Pedoman Penanganan Perkara Pidana dengan Subjek Hukum Korporasi (selanjutnya disebut PerJA Tahun 2014). Hal-hal yang terkait dengan pertanggungjawaban HAM Korporasi dalam lampiran PerJA Tahun 2014 yaitu diuraikannya dengan jelas kegiatan korporasi yang dapat dimintakan pertanggungjawaban, yang mencakup: a) semua perbuatan yang didasarkan pada keputusan pengurus, b) berbuat atau tidak berbuatnya seseorang untuk kepentingan korporasi, c) perbuatan yang menggunakan sumber daya manusia, dana, atau dukungan/fasilitas korporasi, d) perbuatan yang dilakuka oleh pihak ketiga atas permintaan atau perintah dari korporasi atau pengurus korporasi, e) perbuatan dalam rangka menjalankan kegiatan sehari-hari korporasi, f) perbuatan yang menguntungkan korporasi, g) tindakan yang biasanya diterima oleh korporasi, h) korporasi yang secara nyata menampung hasil tindak pidana.

Pengaturan pertanggungjawaban korporasi yang juga dapat diselaraskan dengan UU Nomor 39 Tahun 1999 tentang HAM yaitu UU Nomor 39 Tahun 2014 tentang Perkebunan. Ketentuan Pasal 113 ayat (1) UU Nomor 39 Tahun 2014 mengatur:

(1) Dalam hal perbuatan sebagaimana dimaksud dalam Pasal 103, Pasal 104, Pasal 105, Pasal 106, Pasal 107, Pasal 108, dan 109 dilakukan oleh korporasi, selain pengurusnya dipidana berdasarkan Pasal 103, Pasal 104, Pasal 105, Pasal 106, Pasal 107, Pasal 108, dan Pasal 109, korporasinya dipidana dengan pidana denda maksimum ditambah $1 / 3$ (sepertiga) dari pidana denda dari masing-masing tersebut.

Jika dianalisis secara mendalam maka UU Nomor 39 Tahun 2014 menganut individual vicarious liability karena terdapat pemidanaan terhadap pengurus atas tindak pidana yang dilakukan untuk korporasi. Tindak pidana ini tidak saja dapat dilakukan oleh pengurus namun juga dapat dilakukan oleh pegawai bawahan atau oleh korporasi tersebut.

Ketentuan UU Nomor 39 Tahun 2014 juga memberikan kemunkinan diterapkan-nya sanksi denda kepada korporasi. Teori pertanggungjawaban korporasi yang digunakan dalam undangundang ini yaitu teori corporate vicarious 
liability, teori agregasi, teori identifikasi, dan teori budaya korporasi.

\section{Pertanggungjawaban Korporasi Terhadap Perusakan Lingkngan Menurut Instrumen HAM Internasional}

Pada tahun 1990-an permasalahan bisnis dan HAM telah diakui oleh seluruh dunia masuk ke dalam agenda kebijakan global yang secara dramatis menunjukkan pengembangan internasional dari sektor swasta pada masa itu, seiring dengan peningkatan aktivitas ekonomi antar negara. ${ }^{31}$ Berikutnya perkembangan ini meningkatkan kesadaran sosial terhadap akibat dari aktivitas bisnis dan HAM dan juga menjadi sorotan PBB. ${ }^{32}$ Kesadaran masyarakat internasional untuk meminta pertanggungjawaban HAM korporasi telah digerakkan oleh banyaknya kasus-kasus pelanggaran HAM.

Pada saat pembahasan Statuta Roma berkembang gagasan terhadap pertanggungjawaban korporasi dalam kasus pelanggaran HAM. Perwakilan dari Perancis pernah mengusulkan proposal pertanggungjawaban korporasi yang memicu pro dan kontra saat melakukan negosisasi Statuta Roma Pembahasan pembentukan Mahkamah Pidana Internasional (International Criminal Court (ICC)). ${ }^{33}$ Proposisi negara-negara yang mendukung korporasi yaitu bahwa aspek penghukuman ini masih dibutuhkan untuk memberikan keadilan bagi setiap korporasi yang melakukan pelanggaran terhadap international customary law dan ius cogens dan atau korban. ${ }^{34}$ Negaranegara yang menentang

31 Elsam, Kerangka Perserikatan Bangsa-Bangsa "Perlindungan, Penghormatan, dan Pemulihan, (Jakarta: Elsam, 2014), hlm. 1.

32 Ibid.

33 Patricia Rinwigati, Menjangkau Tanggung Jawab Pidana Korporasi: Altenratif Penyelesaian Pelanggaran HAM, (Jakarta: Elsam, 2016), hlm. 173.

34 Ibid. pertanggungjawaban korporasi memiliki proposisi bahwa praktik pertanggungjawaban pidana korporasi tidak selaras dengan prinsip pelengkap (complementary). ${ }^{35}$ Asas pelengkap itu sendiri yaitu kehadiran Mahkamah Pidana Internasional tidak didirikan untuk menggantikan fungsi sistem nasional, tetapi menjadi alternatif apabila pengadilan nasional tidak efektif. ${ }^{36}$

Meskipun Statuta Roma telah mengatur agar penentuan unwilling dan unable merupakan kewenangan dari Mahkamah, namun tetap terdapat keraguan tentang apa yang menjadikan suatu keadaan unwilling atau unable bagi suatu negara. Untuk itu dibutuhkan suatu cara yang lebih objektif dalam menilai pelaksanaan sistem hukum dan yudisial suatu negara. Jika ingin dianggap mampu melaksanakan proses peradilan maka sistem peradilan negara tersebut harus bersifat independen. Indikator dari independensi peradilan adalah sistem yudisial yang imparsial, dengan keputusan yang dihormati dan diimplementasikan tanpa campur tangan pemerintah. ${ }^{37}$

Hal ini menghendaki perbaikan pada dua sisi yaitu baik dari ketentuan Statute Roma itu sendiri yang memberikan definisi dan mekanisme yang menjamin suatu cara yang lebih objektif dalam menilai pelaksanaan sistem hukum dan yudisial suatu negara maupun perbaikan dari implementasi sistem hukum dan lembaga peradilan secara nasional di negara Indonesia sendiri. Lembaga peradilan harus dilaksanakan secara mandiri tanpa intervensi atau campur tangan dari pihak manapun dan putusan

Ibid.

36 Ibid.

37 Mathem Stephenson, Judicial Independence: What is it, How It Can Be Measured, Why It Occurs,

http://www1.worldbank.org/publicsector/lega l/judicialindependence.htm, diakses pada 1 Oktober 2011. 
hakim harus tidak boleh memihak selain memihak kebenaran berdasarkan faktafakta yang diperoleh dari proses persidangan.

Sejarah

pertanggungjawaban

korporasi dalam pelanggaran HAM ditunjukkan pula oleh usul dari PBB.

Dewan HAM dan Ekonomi Sosial PBB pada tahun 1970-an pernah meminta Sekretaris Jenderal untuk membentuk eminent person yang bertugas mempelajari akibat korporasi multinasional pada proses pembangunan, khususnya di negara berkembang dan bertujuan mewujudkan terjalinnya hubungan internasional. ${ }^{38}$

Di samping itu, terdapat pula negara yang telah mengakui korporasi bertanggung jawab terhadap pelanggaran HAM. Diberlakukannya The Alien Tort Claims Act atau dikenal pula dengan istilah Alien Tort Statute di Amerika Serikat telah disahkan sejak 1789 , orang asing yang berada di luar Amerika Serikat juga dapat menggunakan The Alien Tort Statute (ATS) tersebut untuk menuntut pejabat pemerintah dan atau swasta, dan korporasi karena pelanggaran HAM atau karena penyiksaan. ${ }^{39}$

ATS menekankan bahwa "The term of ATS confer upon the federal district court original jurisdiction over "any civil action" by an alien for a tort only, committed in the violation of the law of the nations". ${ }^{40}$ Berdasarkan ketentuan ATS tersebut, menurut pengkajian penulis ATS menekankan pengadilan-pengadilan

38 Wahyu Wagiman, Upaya Menjangkau Tanggung jawab Korporasi Sebagai Aktor Pengemban HAM: Konstruksi Teoritik Relasi Bisnis dengan HAM di Indonesia dari Perspektif Para Akademisi, (Jakarta: Elsam, 2016), hlm. vi.

39 The Alien Tort Statute: Protecting The Law That Protects Human Rights, Center for Constitutional Rights, (1 Maret 2017), https://ccrjustice.org/home/getinvolved/tools-resources/fact-sheets-andfaqs/alien-tort-statute-protecting-law-protects.

40 Clapham, Op.Cit, hlm. 252. federal di AS memiliki wewenang untuk mengadili pada original jurisdiction setiap gugatan yang diajukan oleh warga negara asing karena pelanggaran HAM yaitu penyiksaan/perbuatan yang tidak manusiawi (tort) yang melanggar hukum nasional. Koporasi yang melanggar hukum pidana internasional baik genosida, perdagangan budak, kejahatan perang, perbudakan, dan kerja paksa dapat diminta pertanggungjawabannya. ${ }^{41}$

Meskipun ATS atau ATCA sangat berguna untuk menegakkan norma HAM, namun cakupannya masih sangat terbatas dan sebaiknya tidak dijadikan jalur penyelesaian masalah terbaik dalam pertanggungjawaban korporasi. Kasus yang disidang di ATCA hanya dapat digugat di pengadilan Federal AS yang jauh dari tempat kejadian sengketa sehingga harus memerlukan bantuan pihak ketiga yang sudah ahli dengan proses peradilan ATCA.

Di samping itu konsep "hukum internasional (law of nations)" cukup sempit karena belum dapat memastikan bahwa hak ekonomi, sosial dan budaya termasuk "hukum internasional".

Kemudian pemerintah dari negara "tuan rumah" juga kurang mengimplementasikan hak asasi manusia, dan sulit untuk mengumpulkan barang bukti dan mewawancarai para saksi di tempat terjadinya sengketa. Berikutnya ongkos dan waktu yang terpakai untuk menggugat kasus pelanggaran ATCA cukup besar. Contohnya kasus Exxon Mobil telah berlangsung selama 6 tahun, kasus Unocal telah berproses selama kurun waktu 9 tahun dan menelan biaya 2 juta Dollar Amerika Serikat.

Organisasi Kerja sama Ekonomi dan Pembangunan (OECD/The Organizational for Economic Co-operation and Development) pada tahun 1976, menerbitkan Guideline for Multinasional

41 Ibid, hlm. 253. 
Enterprises, terdapatnya kasus-kasus kegiatan korporasi multinasional yang ilegal dan tidak beretika telah melatarbelakangi diterbitkan guidelines/ pedoman ini. ${ }^{42}$ Kasus-kasus tersebut yaitu suap Lockheed kepada pejabat-pejabat Jepang untuk memenangkan kontrakkontrak pengadaan alat-alat pertahanan dan keamanan (alutsista), juga keterlibatan ITT dan korporasi-korporasi Amerika Serikat dalam kudeta di Chille pada $1973 .^{43}$

Prinsip-prinsip dan standar-standar praktik yang baik untuk korporasi telah tercantum dalam pedoman tersebut, tetapi panduan tersebut bersifat sukarela (voluntary). ${ }^{44}$

Bab ke IV dari pedoman tersebut, memaparkan korporasi dalam lingkup hukum HAM Internasional dan kewajibankewajiban HAM Internasional di negara di mana korporasi tersebut beraktivitas harus:

1. Menghormati HAM, yang mengandung arti korporasi tidak boleh melakukan pelanggaran HAM, dan harus menyelesaikan pelanggaran HAM yang berdampak buruk di mana korporasi tersebut terlibat;

2. Dalam konteks di mana korporasi tersebut beroperasi, harus mencegah penyebab atau berkontribusi terjadinya pelanggaran HAM yang berdampak buruk;

3. Mencari jalan atau mencegah atau mengurangi terjadinya pelanggaran HAM yang berdampak buruk sebagai akibat langsung dari kegiatan-kegiatan bisnis, produk, dan pelayanan dari korporasi tersebut. Bahkan jika korporasi tersebut tidak berkontribusi adanya pelanggaran HAM tersebut;

4. Mempunyai komitmen kebijakan yang menghormati HAM;

Ibid, hlm. 201.

Ibid.

44 Ibid, hlm. 202
5. Melaksanakan uji tuntas HAM (Human Rights due diligence) sesuai dengan cakupan kegiatannya, sifat dan kontekstual kegiatannya, dan berat ringannya risiko dari dampak pelanggaran HAM tersebut;

6. Menyediakan kerja sama melalui proses yang sah untuk memulihkan dampak buruk dari pelanggaran HAM tersebut di mana korporasi mengidentifikasi hal-hal yang menyebabkan atau berkontribusi terhadap pelanggaran HAM tersebut. ${ }^{45}$

OECD memiliki mekanisme komplain atas pelaksanaan dari panduan tersebut melalui NCP (National Contact Point), tetapi tidak seperti badan peradilan atau quasi peradilan, karena prosedur pengaduan tersebut hanyalah untuk konsultasi, konsiliasi atau mediasi saja. ${ }^{46}$

Telah terdapat 35 negara hingga saat ini yang telah meratifikasi OECD, dan Indonesia belum meratifikasi ketentuan OECD tersebut. ${ }^{47}$ Walaupun negara yang belum meratifikasi ketentuan OECD tetapi apabila ada korporasi antar bangsa yang berasal dari anggota OECD, maka masyarakat/organisasi non pemerintah dapat melakukan pengaduan terhadap implementasi pedoman tersebut kepada National Contact Point (NCP). Setiap anggota berdasarkan pedoman OECD tersebut diwajibkan untuk membentuk NCP untuk memberikan mekanisme pengaduan atas pedoman OECD

45 OECD, OECD Guidelines for Multinational Enterprise 2011 Edition, (Sekretaris Jenderal OECD, 2011), hlm. 31.

46 Clapham, Op.Cit, hlm. 207

47 OECD Membership, Organization For Economic Cooperation and Development (OECD), (6 Mei 2017),

http://www.oecd.org/about/membersandpart ners/\#d.en.194378. 
tersebut. $^{48}$ Beberapa hal bantuan yang disediakan NCP, yaitu: ${ }^{49}$

Memberikan penilaian apakah komplain atas implementasi Panduan OECD itu layak untuk diperiksa lebih jauh, dan jika komplain itu layak diperiksa lebih jauh maka NCP akan berkonsultasi dengan pihak-pihak "bersengketa" dan jika relevan akan meminta nasihat kepada badan-badan relevan, dan atau perwakilan komunitas bisnis, dll., juga menawarkan konsiliasi atau mediasi kepada para pihak.

Penjelasan yang baik tentang tanggung jawab HAM Korporasi lebih spesifik lagi korporasi multinasional yang dapat diminta pertanggungjaabannya apabila melaksanakan pelanggaran HAM telah dimuat oleh panduan OECD untuk korporasi Multinasional. Tetapi mekanisme pengaduan itu sendiri memperoleh kritik dari organisasi masyarakat sipil, masyarakat sipil mengkritik keterbukaan dari NCP pada saat proses mediasi/konsiliasi tersebut. ${ }^{50}$

United Nations (UN) Global Compact adalah gerakan secara sukarela dari pemimpin korporasi, institusi akademik atau organisasi masyarakat sipil yang memiliki komitmen untuk melaksanakan sepuluh prinsip PBB tentang Global Compact. $^{51}$ Sesuai dengan ketentuan UN Global Compact maka terdapat 10 prinsip yaitu: ${ }^{52}$

1. Bisnis harus mendukung dan menghormati perlindungan HAM yang diakui secara intenrasional;

2. Bisnis tidak terlibat dalam pelanggaran HAM;

48 OECD dan Elsam, Panduan OECD Bagi Perusahaan-Perusahaan Multinasional Edisi 2011, (Jakarta: OECD \& Elsam, 2015), hlm. 92.

49 Ibid, hlm. 96-97.

50 Clapham, Op.Cit, hlm. 207.

51 Glbal Compact, United Nations Global Compact, (6 Mei 2017), http://www.indoneiagen.org/about_us/ungc.

52 Ibid.
3. Bisnis harus mendukung kebebasan untuk berserikat dan pengakuan efektif atas hak atas collective bargaining;

4. Penghapusan segala bentuk perbudakan dan kerja paksa;

5. Penghapusan segala bentuk buruh anak;

6. Penghapusan diskriminasi di tempat kerja;

7. Bisnis harus mendukung pendekatan kehati-hatian atas tantangantantangan di isu lingkungan hidup;

8. Melakukan inisiatif untuk mempromosikan tanggung jawab atas lingkungan secara maksimal;

9. Mendorong pengembangan dan penggunaan teknologi yang ramah lingkungan;

10. Bisnis harus melawan segala bentuk korupsi termasuk pungutan liar.

Dalam perkembangannya, Global compact ini diikuti dengan lahirnya Panduan perserikatan Bangsa-Bangsa tentang Bisnis dan HAM (UN Guidelines on Bussiness and Human Rights/UNPGs) pada 2011. Pedoman ini terbit berdasarkan gagasan dari John Ruggie, yang ditunjuk oleh Sekjen PBB sebagai Perwakilan Khusus PBB untuk HAM, Korporasi Multinasional dan korporasi lainnya, yang memberikan 3 pilar utama yaitu:

1. Tanggung jawab Negara untuk melindungi HAM dari pelanggaran oleh pihak ketiga, termasuk korporasi, melalui kebijakan, pengaturan, dan keputusan yang layak;

2. Tanggung jawab korporasi untuk menghormati HAM yang dibuktikan dengan tindakan yang serius untuk menghindari pelanggaran HAM oleh pihak lain dan menyelesaikan dampak negatif dari operasi korporasi tersebut. Untuk itu korporasi harus mempunyai komitmen untuk meghormati HAM, melakukan penilaian atas dampak HAM, serta mengintegrasikan prinsip- 
prinsip penghormatan HAM dalam proses, fungsi dan kebijakan internal;

3. Akses yang luas untuk korban pelanggaran HAM untuk memperoleh skema pemulihan efektif melalui cara yudisial, administratif, atau cara lainnya. ${ }^{53}$

Semua upaya internasional untuk mewujudkan peraturan dan mekanisme pertanggungjawaban korporasi yang baik dan aplikatif bagi seluruh negara di dunia belum dapat terwujud dengan baik. Hal ini disebabkan Indonesia bukanlah negara peserta yang menandatangani Panduan OECD untuk korporasi Multinasional sehingga Panduan OECD tersebut tidak dapat diaplikasikan dalam peraturan perundang-undangan yang berlaku di Indonesia.

Demikian pula dengan sepuluh prinsip PBB tentang Global Compact dan Panduan perserikatan Bangsa-Bangsa tentang Bisnis dan HAM hanyalah merupakan instrumen hukum internasional yang bersifat "soft law" sehingga tidak tersedia sanksi atau hukuman bagi pemerintah maupun korporasi yang melanggar ketentuan tersebut. Namun peraturan internasional tersebut dapat dijadikan pedoman bagi Indonesia untuk menyelaraskan semua peraturan perundang-undangan yang terkait dengan pertanggungjawaban korporasi sehingga seluruh korporasi dapat mentaati ketentuan tersebut dalam rangka melindungi hak asasi manusia.

\section{Pertanggungjawaban}

Korporasi

Terhadap Perusakan

Lingkungan

Menurut Putusan-Putusan Pengadilan

Berikut adalah putusan-putusan pengadilan yang mengadili kasus

53 Lembaga Studi dan Advokasi Masyarakat (ELSAM), UNPG's, Desentralisasi dan UMKM: Laporan Penelitian Relevansi Prinsip-Prinsip Panduan PBB Unrtuk Bisnis dan HAM dalam konteks Indonesia (Jakarta, Elsam, 2016), hlm. 1-2. pembakaran hutan dan lahan oleh korporasi yang mengakibatkan menurunnya kualitas lingkungan hidup, dan kesehatan manusia yaitu:

1. PT KA

Majelis Hakim di MARI dalam kasus pidana pembakaran lahan di Kab. Nagan Raya Prov. NAD di dalam pertimbangan hukumnya menjelaskan korporasi mempunyai kebiasaan buruk membuka lahan dengan cara pembakaran lahan dengan maksud untuk menghindari ongkos produksi biaya tinggi yang merusak lingkungan hidup. $^{54}$

Dampak pembakaran lahan untuk membersihkan lahan perkebunan kelapa sawit oleh korporasi tersebut mengakibatkan kerusakan serius terhadap lingkungan hidup, kerusakan lahan gambut, dan menimbulkan gas efek rumah kaca. Dampak pembakaran lahan tersebut telah menyebabkan pencemaran lingkungan yang merupakan pelanggaran hak setiap orang atas lingkungan hidup yang baik dan sehat.

2. IL (PT. KHS)

JPU mendakwa dan menuntut IL selaku manager estate PT. KHS, tetapi majelis hakim di MARI memutuskan perbuatan pidana manager estate dapat diatribusikan kepada korporasi berdasarkan teori pertanggungjawaban pidana fungsional. ${ }^{55}$ Kemudian majelis hakim di dalam pertimbangan hukumnya secara jelas menyebutkan pembakaran lahan oleh korporasi itu telah berkontribusi terjadinya asap selama dua minggu yang mengakibat-kan polusi udara. ${ }^{56}$

3. PT. AP\&I

54 MARI Putusan Tertanggal 5 April 2016 Nomor 1554 K/Pid.Sus/2015, hlm.57.

55 MARI, Putusan Tertanggal 10 Oktober 2012 No. 1363 K/PID SUS/2012, hlm. 63.

56 Ibid. 
Majelis hakim di dalam petimbangan hukumnya juga menjelaskan adanya hubungan antara pembakaran lahan dengan kerusakan lingkungan sebagai akibat pembakaran lahan oleh korporasi tersebut. PN Pelalawan menilai ada fakta-fakta hukum sebagai berikut:

PT AP\&I dengan sengaja membakar dan membiarkan pembakaran di lahan yang ditimbun sehingga telah pula menghasilkan gas rumah kaca selama pembakaran berlangsung dan tentu saja telah membakar lapisan permukaan tanah yang ditimbun tersebut, kedua hal tersebut tentu saja tidak dibenarkan.

Setelah menganalisis berbagai putusan pengadilan tersebut penulis berkesimpulan bahwa putusan-putusan MARI dalam kasus pidana pembakaran lahan oleh PT KA, IL (PT. KHS), dan PT. AP\&l tidak mengungkapkan secara langsung terjadinya pelanggaran HAM secara spesifik lagi hak atas lingkungan hidup yang sehat dan baik oleh korporasikorporasi tersebut tetapi putusanputusan tersebut memuat terjadinya pencemaran lingkungan dan kerusakan ekosistem lingkungan yang disebabkan oleh pembakaran hutan dan lahan oleh korporasi yaitu timbulnya asap akibat pembakaran hutan yang mengakibatkan pencemaran lingkungan serta menurunnya kualitas lingkungan dan kesehatan masyarakat di sekitar terjadinya pembakaran lahan.

Pencemaran dan kerusakan lingkungan hidup merupakan pelanggaran terhadap hak setiap orang atas lingkungan hidup yang baik dan sehat termasuk kualitas lingkungan yang baik dan terbebas dari asap yang dapat mengganggu kesehatan setiap orang.

\section{Penutup}

Berdasarkan pembahasan di atas maka disimpulkan bahwa banyaknya peraturan perundang-undangan mengenai pertanggungjawaban korporasi yang dibuat setelah Undang-Undang HAM pada tahun 1999 menyebabkan UndangUndang Nomor 39 Tahun 1999 tidak sesuai lagi dengan ketentuan peraturan perundang-undangan yang baru sebagaimana ketentuan asas hukum perundang-undangan yang menyatakan peraturan perundang-undangan yang baru mengesampingkan perundangundangan lama atau Lex Posterior Derogat Legi Priori. Pertanggungjawaban korporasi yang belum diatur dalam UU Nomor 39 Tahun 1999 mencakup: definisi pelanggaran HAM yang belum memuat pelanggaran HAM oleh Korporasi, definisi korporasi, penerapan asas primum remedium dalam hukum pidana lingkungan hidup selain pemidanaan terhadap pelanggaran baku mutu air limbah, emisi dan gangguan, penyelesaian sengketa lingkungan hidup di luar pengadilan, gugatan perwakilan kelompok, hak gugat organisasi lingkungan sebagai bentuk partisipasi masyarakat terhadap hak atas lingkungan hidup yang baik, ancaman hukuman minimum di samping maksimum, perluasan alat bukti, keterpaduan penegakan hukum pidana, pengaturan tindak pidana korporasi. dan kegiatan korporasi yang dapat dimintakan pertanggungjawaban.

Kemudian pada tataran hukum internasional, Statuta Roma telah mengatur agar penentuan unwilling dan unable merupakan kewenangan dari Mahkamah Internasional, namun tetap saja terdapat keraguan tentang apa yang menjadikan suatu keadaan unwilling atau unable bagi suatu negara khususnya untuk mengadili pelanggaran HAM yang dilakukan oleh korporasi. Selain itu The Alien Tort Claims Act (ATCA) atau dikenal pula dengan istilah Alien Tort Statute (ATS) di Amerika Serikat yang digunakan orang asing yang berada di luar Amerika 
Serikat untuk menuntut pejabat pemerintah dan atau swasta, dan korporasi karena pelanggaran HAM atau karena penyiksaan, letaknya yang jauh dari negara-negara lain termasuk Indonesia sehingga harus membutuhkan bantuan pihak ketiga yang sudah ahli dengan proses peradilan ATCA. Di samping itu konsep hukum internasional yang ditangani cukup sempit sehingga belum dapat memastikan penyelesaian pelanggaran HAM di bidang hak ekonomi, sosial, dan budaya. Pemerintah yang menyelanggarakan ATCA juga kurang mengimplementaskan HAM sehingga sulit untuk mengumpulkan barang bukti dan mewawancarai para saksi di tempat terjadinya sengketa. Kemudian ongkos dan waktu yang terpakai untuk menggugat pelanggaran HAM juga cukup besar. Selain itu beberapa instrumen HAM Internasional seperti panduan OECD Untuk Korporasi Mulitnasional, Sepuluh Prinsip PBB tentang Global Compact, dan Panduan PBB tentang Bisnis dan HAM hanyalah merupakan instrumen hukum internasional yang bersifat soft law sehingga tidak tersedia sanksi atau hukuman bagi pemerintah maupun korporasi yang melanggar HAM sesuai dengan ketentuan internasional tersebut.

Selanjutnya tidak adanya peraturan perundang-undangan di bidang HAM yang mengatur pertanggungjawaban HAM Korporasi terhadap perusakan lingkungan menyebabkan tidak terdapat PutusanPutusan Pengadilan yang mengungkapkan secara eksplisit pertanggungjawaban HAM korporasi terhadap pelanggaran HAM khususnya hak atas lingkungan hidup yang sehat dan baik yang dilakukan oleh korporasi tersebut.

Berdasarkan simpulan di atas, maka disarankan agar pemerintah segera merevisi UU Nomor 39 Tahun 1999 dengan mengharmonisasikan ketentuan dalam UU HAM tersebut dengan peraturan perundang-undangan yang terkait dengan pertanggungjaaban HAM Korporasi. Ketentuan yang seharusnya diatur dalam UU Nomor 39 Tahun 1999 mencakup: definisi pelanggaran HAM yang belum memuat pelanggaran HAM oleh Korporasi, definisi korporasi, penerapan asas primum remedium dalam hukum pidana lingkungan hidup selain pemidanaan terhadap pelanggaran baku mutu air limbah, emisi dan gangguan, penyelesaian sengketa lingkungan hidup di luar pengadilan, gugatan perwakilan kelompok, hak gugat organisasi lingkungan sebagai bentuk partisipasi masyarakat terhadap hak atas lingkungan hidup yang baik, ancaman hukuman minimum di samping maksimum, perluasan alat bukti, keterpaduan penegakan hukum pidana, pengaturan tindak pidana korporasi. dan kegiatan korporasi yang dapat dimintakan pertanggungjawaban.

Kemudian pemerintah melalui perwakilannya di PBB mengajak negaranegara anggota PBB lainnya untuk merevisi ketentuan Statuta Roma dengan memberikan ketentuan yang tegas dan rasional tentang apa yang menjadikan suatu keadaan unwilling atau unable bagi suatu negara khususnya untuk mengadili pelanggaran HAM yang dilakukan oleh korporasi. Sebelum mendirikan pabrik atau perusahaannya di Indonesia maka pihak pemerintah dan pihak korporasi sebaiknya membuat perjanjian yang mencantumkan klausul apabila terjadi wan prestasi atau perbuatan yang melanggar HAM maka sengketa HAM tersebut akan diselesaikan oleh lembaga litigasi atau lembaga alternatif penyelesaian sengketa Indonesia sehingga menggunakan jasa praktisi hukum dari Indonesia, dapat menyelesaikan seluruh pelanggaran HAM termasuk pelanggaran HAM korporasi di bidang ekonomi, sosial dan budaya, mengutamakan kepentingan nasional, dan menggunakan ongkos dan waktu 
yang efisien untuk menyelesaikan pelanggaran HAM yang dilakukan oleh korporasi. Pemerintah dapat menjadikan Panduan OECD untuk Korporasi Multinasional, Sepuluh Prinsip PBB tentang Global Compact, dan Panduan Perserikatan Bangsa-Bangsa tentang Bisnis dan HAM dapat dijadikan pedoman bagi Indonesia untuk menyelaraskan semua peraturan perundang-undangan yang terkait dengan pertanggungjawaban korporasi dan pemerintah Indonesia dapat mengatur pemberian sanksi administrasi, pidana, dan perdata terhadap korporasi yang melanggar HAM sehingga dalam melaksanakan seluruh kegiatan atau aktivitas bisnisnya korporasi tersebut senantiasa sangat memperhatikan hak asasi manusia.

Selanjutnya pemerintah segera merevisi seluruh peraturan perundangundangan yang mengatur pelangaran HAM khususnya pelanggaran hak atas lingkungan hidup yang sehat dan baik yang dilakukan oleh korporasi beserta penanganan terhadap pelanggaran HAM tersebut oleh institusi yang berwenang dan terkait, dan juga mengatur sanksi administrasi, pidana dan perdata untuk mempertanggungjawabkan pelanggaran HAM oleh korporasi tersebut. Hal ini sangat penting agar menjadi pedoman bagi seluruh institusi yang berwenang dan terkait untuk menangani pelanggaran HAM khususnya pelanggaran hak atas lingkungan hidup yang sehat dan baik dengan memperhatikan seluruh aspekaspek hak asasi manusia mulai dari proses penyelidikan, penyidikan, penuntutan, peradilan bahkan pada saat menggunakan alternative dispute resolution, dan dalam memberikan ganti kerugian terhadap masyarakat yang menderita akibat kegiatan korporasi dan terhadap pemulihan lingkungan hidup serta dalam upaya pengawasan kegiatan korporasi dan upaya peningkatan hubungan yang baik antara korporasi dengan masyarakat di sekitar korporasi tersebut beraktivitas. 


\section{DAFTAR PUSTAKA}

\section{A. Buku}

Assiddiqie, Jimly, Green Constitution: Nuansa Hijau UUD Republik Indonesia Tahun 1945 (Jakarta: Rajawali Press, 2009).

Clapham, Andrew, Human Rights Obligations of Non-State Actor (Oxford: Oxford University Press).

Cragg, Business and Human Rights: Principle and Value-Based Analysed, artikel di dalam buku Bussiness and Human Rights (Massachusset: Edward Elgar Publishing Inc, 2012).

Elsam, Kerangka Perserikatan Bangsa-Bangsa "Perlindungan, Penghormatan, dan Pemulihan (Jakarta: Elsam, 2014).

$\mathrm{H}$ Knox, John, Report of the Independent Expert On The Issue of Human Rights Obligations Relating to The Enjoyment od A Safe, Clean, Healthy and Sustainable Environment (Geneva: Human Rights Council, 2013).

Ibrahim, Johny, Teori dan Metodologi Penelitian Hukum Normatif (Malang: Bayumedia, 2005).

Komnas HAM, Laporan Tahunan Komnas HAM 2015 (Jakarta: Komnas HAM, 2016).

L. Cohen, Morrish and Kent C Olson, Legal Research In A Nutshell (St.Paul Minn: West Publishing Co, 1992).

L Coleman, Jules, Risks and Wrongs (Cambridge: Cambridge University Press, 1992).

Lembaga Studi dan Advokasi Masyarakat (ELSAM), UNPG's, Desentralisasi dan UMKM: Laporan Penelitian Relevansi Prinsip-Prinsip Panduan PBB Unrtuk Bisnis dan HAM dalam konteks Indonesia (Jakarta, Elsam, 2016).

Marzuki, Mahmud Peter, Penelitian Hukum Edisi Revisi (Jakarta: Prenada Media Group, 2014).

OECD dan Elsam, Panduan OECD Bagi Perusahaan-Perusahaan Multinasional Edisi 2011 (Jakarta: OECD \& Elsam, 2015).

OECD, OECD Guidelines for Multinational Enterprise 2011 Edition (Sekretaris Jenderal OECD, 2011).

Parliament of New South Wales, Legislation Review Committee: Strict and Absolute Liability Discussion Paper (NSW: Parliament of New South Wales, 2006). 
Rinwigati, Patricia, Menjangkau Tanggung Jawab Pidana Korporasi: Alternatif Penyelesaian Pelanggaran HAM (Jakarta: Elsam, 2016).

Ritonga, A, Korporasi Yang Melakukan Tindak Pidana Korporasi Pada Pasal 20 UU No. 31 Tahun 1999 jo. UU No. 20 Tahun 2001 Tentang Pemberantasan Tindak Pidana Korupsi Menurut Perspektif Fiqih Jinayah (Pekanbaru: UIN Sultan Syarif Kasim Riau, 2015).

T Jackson, Kevin, The Normative Logic of Global Economic Governance: In Pursuit of NonInstrumental Justification for The Rule of Law and Human Rights.

Wagiman, Wahyu, Upaya Menjangkau Tanggung jawab Korporasi Sebagai Aktor Pengemban HAM: Konstruksi Teoritik Relasi Bisnis dengan HAM di Indonesia dari Perspektif Para Akademisi (Jakarta: Elsam, 2016).

Wibisono, Makarim, Perlindungan HAM dan Pelanggaran HAM oleh Korporasi dalam Sistem Hubungan Internasional di dalam buku Relasi Bisnis dan HAM Konteks dan Perspektif Hukum di Indonesia (Jakarta: Elsam, 2017).

\section{B. Artikel Dalam Jurnal}

De Brabandere, Eric, "Non State Actors, State Centrism and Human Rights Obligations", Leiden Journal of International Law, 22 (2009).

Insa Ansari, Muhamad, Implikasi Pengaturan Lingkungan Hidup terhadap Peraturan Perundang-undangan Dalam Kegiatan Bisnis (Perspektif Konstitusi), Jurnal Konstitusi (MK) Volume 11 Nomor 2, 2014.

Irawan Febriansyah, Ferry, Konsep Pembentukan Peraturan Perundang-undangan Di Indonesia, Perspektif, Volume XXI No. 3 Tahun 2016 Edisi September.

Komnas HAM, Komentar Umum atas Kovenan Hak-Hak Sipol dan Ekosob, Jakarta: Komnas HAM, 2009.

Kristian, Urgensi Pertanggungjawaban Pidana Korporasi, Jurnal Hukum dan Pembangunan Tahun Ke-44 No. 4 Oktober-Desember, 2013.

Lexis-Nexis, "An Introduction to legal Research".

Palmer, Vernon, "A General Theory of The Inner Structure of Strict Liability: Common Law, Civil Law, and Comparative Law", Tulane Law Review, Vol. 62, (1988).

Priyanta, Maret, "Penerapan Tindak Pidana Lingkungan Bagi Korporasi dalam Penegakan Hukum Lingkungan di Indonesia", Jurnal Law Review Fakultas Hukum Universitas Pelita Harapan (UPH) Vol. XI Nomor (3 Maret 2012).

\section{Koran/ Majalah}

Srict Liability di dalam Kasus Pembakaran Hutan, Harian Kompas, (10 Februari 2017). 
Adoniati Meyria, "Pertanggungjawaban Pidana Korporasi Dalam Pelanggaran HAM Berat", Majalah Wacana HAM Komnas HAM (Edisi 1 tahun XI 2013).

D. Internet

Legal Information Institute, "Abnormally Dangerous Activity", https://www.law.cornell.edu/ wex/abnormally_dangerous_activity (diakses 7 Mei 2017).

OECD Membership, "Organization For Economic Cooperation and Development (OECD)", http://www.oecd.org/about/membersandpartners/\#d.en.194378 (diakses $6 \mathrm{Mei}$ 2017).

Stephenson, Mathem, "Judicial Independence: What is it , How It Can Be Measured, Why It Occurs", http://www1.worldbank.org/publicsector/legal/judicialindependence.htm, (diakses 1 Oktober 2011).

The Alien Tort Statute: "Protecting The Law That Protects Human Rights, Center for Constitutional Rights", https://ccrjustice.org/home/get-involved/toolsresources/fact-sheets-and-faqs/alien-tort-statute-protecting-law-protects (diakses 1 Maret 2017).

United Nations Global Compact, Global Compact, http://www.indoneiagen.org/ about us/ungc (diakses 6 Mei 2017).

\section{E. Peraturan Perundang-undangan dan Putusan}

Undang-Undang Dasar Negara Republik Indonesia Tahun 1945.

MARI, Putusan Tertanggal 18 Agustus 2016, Nomor 460 K/Pdt/2016.

MARI, Putusan Tertanggal 5 April 2016 Nomor 1554 K/Pid.Sus/2015. 